\title{
To seek and save the lost: human trafficking and salvation schemas among American evangelicals
}

\author{
Austin Choi-Fitzpatrick* \\ School of Public Policy, Central European University, Nador 9, Budapest, 1051 Hungary
}

(Received 4 December 2013; accepted 12 May 2014)

\begin{abstract}
American evangelicals have a history of engagement in social issues in general and anti-slavery activism in particular. The last 10 years have seen an increase in both scholarly attention to evangelicalism and evangelical focus on contemporary forms of slavery. Extant literature on this engagement often lacks the voices of evangelicals themselves. This study begins to fill this gap through a qualitative exploration of how evangelical and mainline churchgoers conceptualize both the issue of human trafficking and possible solutions. I extend Michael Young's recent work on the confessional schema motivating evangelical abolitionists in the 1830s. Through analysis of open-ended responses to vignettes in a survey administered in six congregations I find some early support for a contemporary salvation schema. It is this schema, I argue, that underpins evangelicals' framing of this issue, motivates their involvement in antislavery work, and specifies the scope of their critique. Whereas antebellum abolitionists thought of their work in national and structural terms contemporary advocates see individuals in need of rescue. The article provides an empirical sketch of the cultural underpinnings of contemporary evangelical social advocacy and a call for additional research.
\end{abstract}

Keywords: religion; social movements; slavery; human trafficking; human rights; advocacy

\section{Introduction}

The last decade has seen increased attention to two seemingly unrelated issues: the rise of American evangelicals to political and social prominence and the emergence of human trafficking and modern slavery as a prominent issue in contemporary society. Evangelicals' aid in George W. Bush's election to the United States' presidency brought them to the political fore and into the academic spotlight (Lindsay, 2007; B. G. Smith \& Johnson, 2010). At the same time, an unusual union was being forged between second-wave feminists and evangelicals concerned with social justice (Hertzke, 2004). This union proved critical in defining

\footnotetext{
*Email: choifitza@ceu.hu
} 
the United States' political, economic, and discursive responses to human trafficking (Berman, 2006; Shapiro, 2004). As a result, evangelicals within governmental, non-governmental and denominational sectors have been essential in the construction of the dominant conceptualization of modern slavery and human trafficking, and the means of addressing the issue (Doezema, 2000; Jordan, 2007). Evangelical support came in the form of nonprofit organizations, political appointments, and prominent funding sources (Bernstein, 2007; Soderlund, 2005).

Despite enthusiastic attention and the proliferation of informal advocacy groups, hardly any empirical work has explored the cultural roots of evangelical abolitionism. This is surprising, considering the fact that slavery and abolition have captured evangelical energy intermittently since the late eighteenth century (Quirk, 2011). Evangelicals have been involved in each of the four waves of anti-slavery efforts in the Anglo-Saxon world (Choi-Fitzpatrick, n.d.). This study sets out to answer two questions: how do contemporary evangelicals conceptualize the cause of modern forms of slavery and abolition, and why? Qualitative data are used to analyze evangelicals' conceptualization of both the problem of and solutions to human trafficking. These data show evangelicals to be more likely (than mainline Protestants) to suggest individual-level (rather than structural-level) causes of and solutions to human trafficking. In the concluding discussion I propose the difference between evangelical and mainline respondents is explained by a 'salvation schema' that underpins contemporary evangelical conceptualizations of social change. In the final analysis, this study suggests this schema represents a tradeoff between action and analysis.

Before continuing, a note about key terms is in order. Evangelicalism is a conservative vein of Christianity that emphasizes the authority of the Bible, the importance of Jesus Christ, and the spread of these beliefs through the act of evangelism. On the whole, evangelicalism is associated with more conservative political orientations. Mainline denominations, in contrast, have traditionally focused more on social justice than on the importance of the Bible, the role of Christ and the importance of evangelism (Hammond \& Hunter, 1984). Human trafficking is a form of slavery, where slavery is defined as 'the status or condition of a person over whom any or all of the powers attaching to the right of ownership are exercised') (Allain \& Bales, 2011, p. 3). In my use of the term 'schema' I generally follow Sewell's use to describe 'transposable procedures applied in the enactment of social life' (Sewell, 1992, p. 17), where such procedures are drawn from mental structures that represent some aspect of the world. Bartlett (1932) argues that schemas are transportable; in other words, existing belief can be rearticulated in novel contexts. At its core, this article suggests a belief in spiritual salvation is readily rearticulated as the corporeal salvation of victims of a particularly pernicious human rights abuse. The resulting salvation schema, I argue, provides the theoretical and conceptual framework that helps individuals understand human trafficking. The study begins with (1) an overview of the project's theoretical background, specifically regarding modern slavery and evangelical abolitionism; followed by (2) an 
overview of the methods and data; and (3) a discussion of the results and concluding remarks about their significance.

\section{Background and theory}

\section{Abolitionist evangelicals}

It should now be clear that religion matters for social movements (Hertzke, 2004; Lichterman, 2008; Morris, 1984; Nepstad, 2004; C. Smith, 1996a, 1996b; Wood, 2002; Young, 2002; Wood and Zald, 1987). While evangelicals have a long history of public activism (Grittner, 1986; Hochschild, 2005; Noll, 1994) memorable and recent activism has tended to center on abortion and homosexuality (Fetner, 2008; Munson, 2008). A gradual shift has been noted, however, as evangelical efforts have broadened to cover a wider array of social, political, and economic issues (Lindsay, 2007), including environmental degradation and issues related to debt and trade (Bernstein, 2010) and a host of other issues (Steensland $\&$ Goff, 2014). While a steady stream of human rights activists called for greater attention to modern slavery and human trafficking, it wasn't until the late 1990s that an impressive union between second-wave feminists and an emerging brand of evangelicals drove the issue to the center of policy, funding, and popular discourse (Heltzel, 2009; McDonald, 2004). While these two communities disagreed on other issues, they united in their conceptualization of human trafficking as an issue primarily involving the sexual exploitation of women and children (Outshoorn, 2005). Of course this conceptualization is narrower than more mainstream definitions, which consider trafficking to be a human rights issue impacting on women, children, and men who are victims of both sexual and labor exploitation (Bales, 2012; United Nations, 2000).

As Soderlund has observed, the rhetoric used by these groups - and prevalent in the anti-trafficking regime during the Bush Administration - is 'historically and institutionally embedded' as there are 'few ways to talk about sex trafficking that do not include dramatic readings of the captivity narrative's well-rehearsed scripts: the prison-like brothel, the lured or deceived female victim, and her heroic rescuer' (Soderlund, 2005, p. 77). This image - of an ideal-type victim in complete captivity - predominates in press accounts (Kristof, 2004; Landesman, 2004), popular culture (Berman, 2010) and was institutionalized in federally funded programs (Jordan, 2007; Weitzer, 2007). This model is premised on the idea that trafficking is primarily an individual problem requiring individual-level intervention. The individual-level approach sees trafficking emerging from the actions of individuals and the solution being to rescue individual victims while arresting and pressing charges against perpetrators. This model has been characterized as a 'law and enforcement' approach, in contrast to the 'human rights' approach that conceptualizes trafficking and slavery in terms of complex social relations and cultural conditions that both perpetrators and enslaved persons are embedded in and focuses on the empowerment of trafficked persons in political and economic systems (Brysk \& Choi-Fitzpatrick, 2012; Choi-Fitzpatrick, 2012, n.d.). The human 
rights perspective can be seen in the approach taken by the Church of the Brethren, who in 2007 signed a statement on slavery and trafficking. The statement is their ninth since 1797 and reads in part 'We confess our complicity in the global network of slavery through consumption of goods and services that have been produced by slave labor' (Church of the Brethren, 2008). This conceptualization of slavery as a structural issue requiring social, political, and economic solutions can be readily contrasted with the law and enforcement approach. While the Church of the Brethren is not a mainline denomination, it is a member of the National Council of Churches and shares many social justice commitments with the mainline churches considered in this article.

Scholarly efforts to explain evangelical engagement tend to argue that the current anti-trafficking regime is both colonial and dismissive of individual agency (Berman, 2006; Desyllas, 2007) and has its roots in anti-immigration regimes (Sharma, 2005), moral crusades (Soderlund, 2005), political opportunities (McDonald, 2004), or heteronormative projects (Vance, 2011). Unfortunately, this literature treats evangelical engagement instrumentally rather than culturally, as if abolitionism is rooted in a fear of migrants or a desire to retain or project cultural power. While these interpretive analyses have identified evangelicals' role and impact, they missed an opportunity to explore evangelicals' motives with nuance and care.

\section{Evangelical abolitionist schemas: 1830 and 2010}

The challenge, then, is to explore how evangelicals actually conceptualize the root cause of slavery and trafficking. Over the past two decades, social movement scholars have significantly advanced our understanding of the cultural resources available for communicating movement messages to actual and potential supporters, as well as the general public. A cottage industry has cropped up around David Snow et al.'s (1986, p. 464) innovative extension of Erving Goffman's (1974, p. 21) concept of frame - the 'schemata of interpretation' - to social movements. Yet framing's popularity, and the subsequent rush to produce an exhaustive catalogue of frames, often circumvents the question of why frames resonate (Johnston, 1995; McAdam, McCarthy \& Mayer, 1996; but see Benford, 1997 on framing's critics). More authentic narratives, detractors contend, are sourced in 'shared meanings created through sustained interaction' (Fitzgerald, 2009, p. 194, fn 4) and the 'shared understanding and their representations' that comprise culture (Tilly, 1997, p. 42; Zhao, 2010). It is therefore crucial that efforts to 'understand the beliefs and values that motivate action ... look beyond the presentation of ideas, to the subjective commitments to belief' (Gillan, 2008, p. 251).

Michael Young $(2002,2006)$ has made particularly insightful use of the notion of schemas, especially related to evangelical involvement in the American social movement to end slavery. He argues that schemas provide ontological security, and that unsettled moments, novel institutional differentiation, rapid expansion of markets and the disruption of traditional social arrangements lead to either 
the destruction of a schema, or its extension in novel and unpredictable ways (e.g., social movements) (Young, 2002, p. 666, 2006, p. 33). As Sewell (1992) originally observed, schemas are also transposable, in that they can be applied to cultural material and phenomena beyond the context in which they are originally learned. In this way Young follows Sewell $(1992,1996)$ in arguing that 'cultural mechanisms that combine intensive and extensive schemas command significant material and human resources, including emotions' (Young, 2006, p. 35; see also Young, 2002).

Young draws on abolitionist efforts by evangelicals in the 1830 s to demonstrate his theory of schema extension. Specifically, Young (2006) argues that a 'cultural mechanism combining schemas constitutive of the evangelical cosmos launched and sustained these movements by mobilizing human and material resources within para-church institutions to new and startling purposes' (p. 17). It is the evangelical experience of salvation (conversion) combined with a sense of sin that 'provided the vocabulary and method' to anti-slavery efforts (Young, 2006, p. 26; see also Davis, 1962; Loveland, 1966). Specifically, the evangelical religious schema of immediate justification (through pure potential in grace) laid the groundwork for the concept of immediate emancipation (through limitless agency) (Davis, 1962, p. 228). This concretization of sacred concepts proved crucial to the critical movement framing slavery as a national sin (Loveland, 1966, p. 182, fnn 34 and 35). ${ }^{1}$

The concept of individual sin continued to be salient long after the abolitionist era. Wuthnow (1999, p. 338) has pointed out that ' $[\mathrm{w}]$ hereas the mainline churches participated in progressive social betterment programs during the first half of the twentieth century, evangelical churches focused more on individual piety' (see also Hunter, 1982, 1987). This individualism can also be seen as a key component of the evangelical Protestant worldview, which involves being certain of one's beliefs, reflecting frequently about life, and - perhaps most importantly having a 'born-again experience' in which a person is 'saved' (Hammond \& Hunter, 1984, p. 224). Aspects of belief and practice reflect a strong emphasis on individual piety and include the importance of Bible-reading and church attendance, and conservative attitudes regarding the notion of the family, social behaviors, and religion in the public square (Hammond \& Hunter, 1984).

Contemporary anti-trafficking efforts gain additional nuance when compared to evangelical abolitionism in the 1830s. Then, as now, evangelical social action took place in a broader context, as the moorings and meanings of economic and social life were shaken to their core. It was in this milieu that evangelicals of the past rooted their advocacy in schemas of $\sin$ and confession that had their roots in tent revivals and acts of benevolence (Young, 2002, p. 664). The result was a structural critique of legal and institutionalized slavery (Young, 2006). Similarly, contemporary evangelical abolitionists have rooted their advocacy in schemas of sin and salvation that, combined with increasing levels of individualism, have resulted in fundamentally individual critiques of illegal and ad hoc slavery. Thus, while evangelicals circa 1830 had a 'nationally extensive and introspective moral project' of saving the nation from collective sin (Young, 2006, p. 201), this 
research explores the possibility that contemporary evangelical abolitionism is a globally oriented and externally focused moral project that draws inspiration and energy from the analogous salvation of individual victims from $\sin$.

\section{Research strategy and data collection}

This study focuses on the relationship between religious worldview and structural conceptualizations of modern slavery by analyzing responses to a web-based survey administered to individual attendees of mainline and evangelical churches in four American states: California, Florida, Massachusetts and Connecticut. In order to ensure variation in individual respondents, and to determine (or 'control for') any impact from church-level engagement in the issue, I selected congregations that varied on religious tradition and church-level involvement in anti-human trafficking efforts (see Table 1, below).

Each of the mainline churches was historically progressive, inclusive of members regardless of gender, ethnicity, economic status, or sexual orientation, and had regular social justice programming oriented around human and civil rights, affordable housing and medical care, and social and environmental justice. All the evangelical churches were similar in their non-denominational culture and a commitment to serve as a point of connection between people and between individuals and God. A total of 202 respondents completed the survey. The non-random sampling strategy played well off the web-based survey method to ensure variation in religious beliefs while over-representing those individuals most likely to be involved in anti-slavery and trafficking work (single, middle-class, Caucasian women).

I analyze the effects of an evangelical worldview on the propensity to think structurally about both causes of and solutions to slavery issues using responses to vignettes about modern day slavery. This experimental design allowed me to cross gender with type of abuse (for a total of four conditions) in fictional cases of human trafficking and to then randomly assign two vignettes to each respondent

Table 1. Basic description of churches in study.

\begin{tabular}{lcccc}
\hline & Evangelical & Engaged & $\mathrm{N}$ & $\%$ \\
\hline Orlando Evangelical Church & $\mathrm{Y}$ & $\mathrm{Y}$ & 77 & $38 \%$ \\
Boston Evangelical Church & $\mathrm{Y}$ & $\mathrm{N}$ & 71 & $35 \%$ \\
San Diego Evangelical Church & $\mathrm{Y}$ & $\mathrm{Y}$ & 15 & $7 \%$ \\
& & & $\mathbf{n}=\mathbf{1 6 3}$ & $\mathbf{( 8 0 \% )}$ \\
Boston Mainline Church & $\mathrm{N}$ & $\mathrm{N}$ & 28 & $17 \%$ \\
Connecticut Quakers & $\mathrm{N}$ & $\mathrm{Y}$ & 6 & $3 \%$ \\
Boston Progressive Church & $\mathrm{N}$ & $\mathrm{N}$ & 5 & $2 \%$ \\
& & & $\mathbf{n}=\mathbf{3 9}$ & $\mathbf{( 2 0 \% )}$ \\
& & & $\mathbf{N}=\mathbf{2 0 2}$ & $\mathbf{1 0 0 \%}$ \\
\hline
\end{tabular}


(Table 2). While it is possible that some evangelical respondents might have trouble accepting the vignette combination that placed a male subject in a situation of sexual exploitation, there is no evidence that this biased their responses. Indeed,

Table 2. Vignette variance.

\begin{tabular}{|c|c|}
\hline & Labor exploitation \\
\hline Male & $\begin{array}{l}\text { José recently lost his good paying job } \\
\text { in a factory and can no longer afford } \\
\text { to support his family. Unfortunately, } \\
\text { there was little other work available } \\
\text { in the area and he ran out of options } \\
\text { there. When he was approached by } \\
\text { someone who told him of a job at a } \\
\text { produce stand in a nearby town, and } \\
\text { offered to take him, he was } \\
\text { desperate. Although the job paid less } \\
\text { than most, including his old factory } \\
\text { job, he believed taking the stranger } \\
\text { up on the offer was the best way to } \\
\text { support himself and his family. }\end{array}$ \\
\hline
\end{tabular}

Soon after arriving, the farmer informed him that he would not be working in the produce stand, but as a farmhand picking tomatoes twelve hours a day. When he threatened to leave, the farmer insisted that he owed him for helping him and would harm him and his family if he left.

Female Maria also lost her job when the factory closed. Unable to provide for her family, she was also approached by someone who told her of a job at a produce stand in a nearby town, and offered to take her, she was desperate. Although the job paid less than most, including her old factory job, she believed taking the stranger up on the offer was the best way to support her and her family.

Soon after arriving, the farmer informed her that she would not be working in the produce stand, but as a farmhand picking tomatoes twelve hours a day. When she threatened to leave, the farmer insisted that she owed him for helping her and would harm her and her family if she left.
Sexual exploitation

José recently lost his good paying job in a factory and can no longer afford to support his family. Unfortunately, there was little other work available in the area and he ran out of options there. When he was approached by someone who told him of a job at a nail salon in the capital city, and offered to take him, he was desperate. Although the job paid less than most, including his old factory job, he believed taking the stranger up on the offer was the best way to support himself and his family.

Soon after arriving in the city, his new boss informed him that he would not be working in the salon, but as a prostitute in a brothel next door. When he threatened to leave, the salon owner insisted that he owed him for helping him and would harm him and his family if he left.

Maria also lost her job when the factory closed. Unable to provide for her family, she was also approached by someone who told her of a job at a nail salon in the capital city, and offered to take her, she was desperate. Although the job paid less than most, including her old factory job, she believed taking the stranger up on the offer was the best way to support her and her family.

Soon after arriving in the city, her new boss informed her that she would not be working in the salon, but as a prostitute in a brothel next door. When she threatened to leave, the salon owner insisted that she owed him for helping her and would harm her and her family if she left. 
not a single respondent identified this combination as problematic. This may be early evidence of increased acceptance of alternative sexual preferences, or it may be further proof of the salvation narrative's power - slavery is so extreme that men are forced to do 'unnatural acts.' The qualitative analysis of openended responses is preferred to more quantitative approaches as it allows for the generation of exploratory propositions and the sketching of 'a probabilistic axis along which to direct [additional] empirical research' (Emirbayer \& Mische, 1998, p. 1006). The goal, then, is to generate hypotheses, rather than make statistical determinations (see Alexander \& Becker, 1978, for an overview of vignettes in survey research and Collett, Guidry, Martin, \& Sager, 2006, for a more recent application).

A demographic overview of respondents' beliefs, attitudes, and demographic attributes allows for the prima facie verification that evangelical churchgoers fall within the accepted contours of the category evangelical. As seen in Table 3, the clear majority of evangelical respondents reported a belief in the central tenets of evangelicalism. While this study intentionally oversamples evangelicals, evangelical respondents, for reasons unknown to the author, tend to be more conservative than the national average. Since the study's questions regarding personal belief are drawn from the General Social Survey (GSS), ${ }^{2}$ data from the most recent GSS are considered to be the 'national average.' For example: 78\% of evangelicals report a perceived image of 'God as Judge,' compared to 93\% of evangelicals sampled in this study. Study respondents report a higher belief in heaven $(86 \%$, v. $99 \%$ in this sample), the devil $(66 \%$ v. $96 \%)$, and 'God as Father' ( $87 \%$ v. 98\%). Despite this occasional divergence, however, the findings correspond very closely to the profile of anti-trafficking supporters found in the existent literature (upper-middle class, educated, politically liberal, predominantly white women).

The vast majority of evangelical respondents (93-99\%) reported a perceived image of God as being a redeemer, father, king, judge, friend, or liberator. A significant (but smaller) percentage of mainline respondents reported perceptions of God as friend, liberator, and redeemer while far fewer mainline respondents report more traditional images of God as father, king, and judge. Theologically, the vast majority of evangelicals report belief in the central evangelical tenets of personal salvation only through Christ, personal sin, heaven, hell, the devil, and structural $\sin$. The majority of mainline respondents report a belief in heaven and personal and structural sin, yet hardly register on the rest of the measures of a more traditional and conservative worldview (e.g., salvation through Christ, or a belief in the devil, an evil world and corrupt human nature). Of interest is the fact that more respondents, mainline and evangelical, believe the world is fundamentally good (55\%) than believe it is evil (18\%), a finding that is modestly echoed in both groups' reported beliefs in the corruption of human nature $(41 \%)$ as opposed to its inherent goodness $(29 \%)$. The clear majority of evangelicals heard about human trafficking in church, while most mainline respondents heard through the media. 
Table 3. Demographic overview of evangelical and mainline respondents.

\begin{tabular}{|c|c|c|}
\hline & Evangelical & Mainline \\
\hline Female & $72 \%$ & $72 \%$ \\
\hline Caucasian & $76 \%$ & $92 \%$ \\
\hline Asian & $13 \%$ & $0 \%$ \\
\hline College degree completed & $69 \%$ & $95 \%$ \\
\hline \multicolumn{3}{|l|}{ Age } \\
\hline$\ldots 18-34$ & $67 \%$ & $31 \%$ \\
\hline$\ldots 35-54$ & $26 \%$ & $33 \%$ \\
\hline$\ldots 55+$ & $7 \%$ & $36 \%$ \\
\hline \multicolumn{3}{|l|}{ Income } \\
\hline$\ldots$ Less than $\$ 40 \mathrm{k} /$ year & $21 \%$ & $15 \%$ \\
\hline$\ldots$ Between $\$ 40 \mathrm{k}$ and $120 \mathrm{k} /$ year & $49 \%$ & $59 \%$ \\
\hline$\ldots$ Greater than $\$ 120 \mathrm{k} /$ year & $13 \%$ & $26 \%$ \\
\hline \multicolumn{3}{|l|}{ Political orientation, somewhat to very ... } \\
\hline ... Politically liberal & $42 \%$ & $97 \%$ \\
\hline ... Politically conservative & $30 \%$ & $3 \%$ \\
\hline Theological orientation, somewhat to very ... & $0 \%$ & $0 \%$ \\
\hline ... Theologically liberal & $26 \%$ & $82 \%$ \\
\hline ... Theologically conservative & $37 \%$ & $8 \%$ \\
\hline \multicolumn{3}{|l|}{ Images of God, definitely or probably ... } \\
\hline ... Redeemer & $99 \%$ & $74 \%$ \\
\hline ... Father & $98 \%$ & $54 \%$ \\
\hline$\ldots$ Friend & $98 \%$ & $82 \%$ \\
\hline ... King & $94 \%$ & $18 \%$ \\
\hline ... Judge & $93 \%$ & $31 \%$ \\
\hline ... Liberator & $93 \%$ & $77 \%$ \\
\hline \multicolumn{3}{|l|}{ Theological worldview, definitely or probably ... } \\
\hline ... Heaven & $99 \%$ & $67 \%$ \\
\hline ... Devil & $96 \%$ & $21 \%$ \\
\hline ... Hell & $94 \%$ & $15 \%$ \\
\hline$\ldots$ Personal sin & $94 \%$ & $82 \%$ \\
\hline ... Personal salvation through Christ only & $83 \%$ & $5 \%$ \\
\hline$\ldots$ Structural sin & $76 \%$ & $72 \%$ \\
\hline ... Corrupt human nature & $48 \%$ & $10 \%$ \\
\hline ... Evil world & $20 \%$ & $0 \%$ \\
\hline \multicolumn{3}{|l|}{ Important or very important in making key decisions ... } \\
\hline ... Bible & $96 \%$ & $41 \%$ \\
\hline ... Holy Spirit & $96 \%$ & $77 \%$ \\
\hline ... Internal compass & $89 \%$ & $100 \%$ \\
\hline \multicolumn{3}{|l|}{ Heard about trafficking through ... } \\
\hline ... Church & $74 \%$ & $36 \%$ \\
\hline ... Media & $58 \%$ & $72 \%$ \\
\hline \multirow{4}{*}{$\begin{array}{l}\text { Got involved by participating in ... } \\
\text {.. Film, lecture, event, book, donating, volunteer, intern, } \\
\text { work }\end{array}$} & & \\
\hline & $73 \%$ & $56 \%$ \\
\hline & $\mathrm{n}=163(80 \%)$ & $n=39(20 \%)$ \\
\hline & \multicolumn{2}{|c|}{$N=202$} \\
\hline
\end{tabular}




\section{Analysis}

Survey data were used to create a database consisting of both vignette responses and supplementary attitudinal and demographic data. Open-ended responses to questions about causes of and solutions to the vignette situations were coded to indicate whether or not respondents used structural language in their explanations. Responses were coded as structural if they referred to macro-level issues or actors (i.e. systems of governance) and were coded as non-structural if they referred to causes or solutions at the individual level (i.e. police intervention in a crime). In those cases where a respondent indicated both structural and non-structural dynamics, an assessment was made as to whether the response was predominantly structural. By predominantly, I mean instances in which the overall attribution (i.e., the 'whole of the response') was interpreted to be structural in its intention. While this definition may not be entirely satisfactory to all readers, a certain degree of interpretation is necessary for such analysis.

An example of this stratagem can be seen in Table 4, where I argue "poverty, greed and insufficient aid' represents a non-structural analysis. The term 'greed' suggests an individual vice, 'aid' suggests a relationship of dependency between the impoverished person and the munificence of a donor; these two interpretations shade my understanding of the term poverty. While the respondent may have meant 'structural poverty,' the proximity to 'greed and insufficient aid' is taken

Table 4. Examples of responses to questions regarding labor and sexual exploitation.

\begin{tabular}{|c|c|}
\hline Examples of problem statements & Examples of solution statements \\
\hline \multirow{3}{*}{$\begin{array}{l}\text { Structural problem: } \\
\text { - 'structural inequalities' } \\
\text { - 'globalization and corruption' }\end{array}$} & Structural solution: \\
\hline & - 'participation in global economy' \\
\hline & $\begin{array}{l}\text { - 'government should be held } \\
\text { accountable' }\end{array}$ \\
\hline $\begin{array}{l}\text { - 'corrupt governments which create } \\
\text { poverty' }\end{array}$ & $\begin{array}{l}\text { - 'provide economic security for all } \\
\text { citizens' }\end{array}$ \\
\hline - 'economic dependence on cheap labor' & - 're-establish true middle class' \\
\hline $\begin{array}{l}\text { - 'systemic poverty, exploitation and } \\
\text { inequality of women' }\end{array}$ & $\begin{array}{l}\text { - 'work with church to educate } \\
\text { vulnerability'* }\end{array}$ \\
\hline - 'human and structural evil’* & \\
\hline \multirow{6}{*}{$\begin{array}{l}\text { Non-structural problem: } \\
\text { - 'coercion' and 'greed' } \\
\text { - 'evil people' } \\
\text { - 'poverty, greed and insufficient } \\
\text { [individual] aid' } \\
\text { - 'financial desperation' } \\
\text { - 'poverty, greed and insufficient aid' }\end{array}$} & Non-structural solution: \\
\hline & - 'provide emergency rescue services' \\
\hline & - ‘job skill training’ \\
\hline & - 'money for people in transition’ \\
\hline & - 'crack down on abusive farmers' \\
\hline & $\begin{array}{l}\text { - 'church intervening to help victim and } \\
\text { family'* }\end{array}$ \\
\hline - 'immorality of employer’* & $\begin{array}{l}\text { - 'spiritual revolution in the hearts of the } \\
\text { perpetrators'* }\end{array}$ \\
\hline
\end{tabular}

Note: * indicates a response that was also coded for spiritual implications or content. 
as an indication that personal poverty is the more likely conceptualization. Responses were additionally coded as 'religious' if they included references to religious causes or solutions (i.e. 'structural evil,' church intervention, etc.).

In addition to the intentional coding of religious and structural attributions, I conducted open coding by studying the vignettes line-by-line (Strauss, 1987). These open codes allowed for the emergence and identification of ideas, concepts, and themes throughout the empirical materials (Charmaz, 2000). A subsequent round of analysis allowed for the grouping of these concepts together into overarching categories critical to understanding respondent perceptions of the causes and solutions to trafficking. In the final process of theoretical coding I drew on the themes emergent from the data, the extant literature, and my own experience. These themes - desperation, education, poverty, and greed as causes, and prosecution, jobs, and laws as solutions - provided critical categories around which I was able to identify theoretically salient variance in responses. As seen in the discussion, the critical difference between mainline and evangelical respondents lies in how they use these concepts and where they locate responsibility.

\section{Perceived causes and solutions to human trafficking}

American evangelical and mainline respondents presented their perspectives on the root problems that give rise to cases of human trafficking, as well as their best accounts of how these cases might be resolved. I began this study in an attempt to discover whether evangelicals are more likely (than their mainline co-religionists) to suggest individual-level causes of and solutions to human trafficking than they would structural-level causes and solutions. Through a comparative analysis of both groups' assessments of problems and solutions, I sketch the contours of a salvation schema that uniquely informs evangelical understandings.

\section{Root causes of human trafficking}

Respondents from both traditions shared a key similarity in that, despite gender or type of exploitation, they consistently identified four causal factors: desperation, poverty, greed, and a lack of education. One typical evangelical respondent suggested that 'sin, deprivation, ignorance, poverty, corruption, [and] lack of options' were to blame, while a typical mainline respondent suggested the problem was deprivation, together with 'insufficient monitoring of human rights.' Education and awareness of the issue were commonly cited, as were poverty and greed ('financial need, ignorance, greed, and evil' in the words of one evangelical). Most respondents identified these factors in clusters, effectively enmeshing the causes with one another. Evangelical assessments - 'poverty, injustice, depravity' - bore a significant and consistent similarity to mainline assessments - 'poverty, lack of education, lack of resources.' Across these accounts it is clear that most respondents see the problem rooted in a lack of a particular thing. Yet there are clearly patterned differences in the nature and form of the lack. 
Beneath these similarities lay the beginning of a fissure between evangelical and mainline accounts. While both report this exploitation as rooted in a particular lack, evangelicals tended to more frequently identify the deficit in relation to individual-level resources and attributes, such as job skills, life options, family support, or police protection. Mainline respondents, on the other hand, locate the problem in a lack of social or structural attributes or resources, such as educational opportunities, legal systems, or broader gender relations.

This fissure widens into a gap upon systematic comparison of the key differences in respondent assessments of causality. In analyzing these points of divergence I have adopted an analytical approach that teases out those mutually exclusive concepts that consistently and accurately reflect the differences between evangelical and mainline respondents, and in so doing highlight the core beliefs and values that inform evangelical advocacy. Where poverty, desperation, greed, and education represent concepts about which there is consistent overlap, the concepts of sin and evil (for evangelicals) and issues related to economics, politics, and culture (for mainline respondents) are core categories that hardly appear in the other group's assessment of the issue. The two broadest categories of mutually exclusive responses that emerged from theoretical coding are related to 'sin' and 'government,' respectively. Where evangelicals consistently highlighted the concepts of sin and evil, and their manifestation as societal, individual, or human 'brokenness,' neither concept appeared a single time in mainline responses.

Spiritual imagery predominated in evangelical accounts of the ways sin, evil, and greed concatenate to drive the vulnerable into exploitation. Typical statements identify the problem as 'sin and selfishness,' 'selfishness, greed, desperation, evil,' 'human wickedness,' and 'a world blinded by sin.' As one respondent from Boston Evangelical succinctly argued in regard to a vignette on sexual exploitation: 'The root cause of a situation like this is evil triumphing in human nature: the greed and depravity of the brothel administrators and the lust and depravity of the brothel customers.' Mainline respondents instead see the issue rooted in a combination of government absence or complicity. In the rare instance in which more spiritual dimensions are invoked, it is often in line with one respondent, who argued that the root of the problem was both a 'Moral decline fostered by Reagan. ... and ... Capitalism and profit as a virtue.'

The problem, one mainline respondent wrote, is 'economic oppression, monopoly of land and resources by individuals and especially corporations,' while another echoed this sentiment, blaming 'government's choice of corporate profits over citizen's well-being.' (Mainline respondents had far more to say than evangelicals on gender, with one representative respondent noting that the instance of sexual exploitation described in the vignette was rooted in 'the objectification and oppression of women.')

These mutually exclusive categories - sin and government - are critical to understanding the deeper cultural resources that contribute to an individual's understanding of how individuals end up in extreme forms of exploitation. From this vantage point, evangelicals can be seen arguing that the forces driving poverty 
and desperation are either personal (lack of education or skills) or cosmic (the presence of sin and evil). The larger story is one of 'evil, poverty, self-centeredness.' In contrast, mainline respondents more consistently argue that the large causal factors behind poverty and desperation tend toward the material and structural (lack of government engagement, lack of jobs, etc.). The data, therefore, highlight the extent to which evangelicals emphasize individual factors: the vulnerability and desperation of the worker, the greed of the oppressor, or the presence of a critical moral failing (e.g., racism, sexism, and deceit).

Two caveats to this finding are in order. The first is the extent to which this analysis draws boundaries across factors - spiritual v. material and individual v. structural - that are often mutually constitutive and reinforcing. The majority of the respondents avoid facile answers, instead responding in ways that reflect a combination of factors that, taken together, allow for an analysis of the underlying schema. The second caveat is related to the handful of evangelicals who framed the problem in spiritual and structural terms. Though outliers, they provide a useful contrast with more typical responses. One relatively conservative attendee $^{3}$ of Boston Evangelical suggested that the problem was 'local, national, and international neglect of God's values of fair distribution of wealth ... People don't reach this level of desperation if they have money, education, power, or voice in their given society. The cause is societal sin.' This respondent is one of the few evangelical respondents to articulate a concept of structural sin. The vast majority of evangelical respondents $(76 \%)$ reported a belief in structural sin, yet few articulated this belief. It should be noted that this finding points to the possibility of transposing the schema of slavery from individual salvation to the theological moorings of structural sin, such as they are.

Both caveats, however, lend additional support to the central thrust of these findings: evangelical respondents tend to identify the root of the problem at the intersection of personal lack (of education, skills, or opportunity) and broader spiritual forces (evil, 'brokenness,' or sin). The victim, then, is seen as in a position of desperation as a result of a combination of factors. It is this personal desperation that requires immediate action directed toward the individual. While recognizing desperation as a critical aspect of the story, mainline respondents tend to emphasize the social factors that both underpin discrimination and serve as the constant backdrop for desperation, rendering the individual experience a manifestation of structural shortcomings. These perspectives frame the nature and scope of solutions advanced by respondents.

\section{Solutions to human trafficking}

Here too a number of critical similarities emerge from the data. Both evangelicals and mainline respondents highlight, though at varying levels, three overlapping solutions: enacting or enforcing laws, punishing perpetrators, and providing jobs. Passing and enforcing laws is important to both communities, with evangelicals suggesting the passage of laws to 'control the sex industry' and 'crack down 
on prostitution' and mainline respondents suggesting 'more governmental oversight' and 'agricultural inspections on farms.'

While there is general agreement on the importance of law enforcement, there is less consistency regarding the punishment of perpetrators and the provision of jobs. Both groups recommend punishing perpetrators, yet specific suggestions from evangelicals tend toward 'criminal action against [the perpetrator]' while mainline approaches display a wider variety of solutions, from 'prosecute human traffickers' to 'confiscate farmers' property.' A finer analysis of the general agreement over the importance of jobs reveals similar fault lines; mainline respondents disproportionately recommend structural solutions, such as 'education and job opportunities for all' and 'jobs that pay a living wage.' Evangelicals, for their part, suggested 'help finding a new job' and 'provid[ing] skills workshops,' with one respondent arguing that 'there needs to be jobs for people who don't have them, but I don't imagine jobs should just be created for no good reason. The answer is not welfare.'

When turning from these three areas of general agreement, the field of recommended solutions fragments rapidly into a host of suggestions that are nearly mutually exclusive to evangelicals and mainline respondents, respectively. It is here where the data provide a window into the ways respondents construct answers (i.e., frame) from latent cultural schemas. This creative process - of actually thinking about solutions - generated far more data than did the question related to cause. For example, an initial round of open coding of all responses to the question regarding the solution generated around $35 \%$ more original codes than did the open coding of responses to the question regarding the problem. This admittedly unscientific observation suggests, however, that the open-ended nature of the logic required by the question invites the respondent to draw on a larger repertoire of meaning and belief.

Evangelicals were more likely to recommend individual-level interventions in the form of rescues, police raids, and the punishment of the perpetrator followed by educational opportunities for the newly emancipated. The form of recommended rescue, of course, varies: from 'liberation of people with clear options' and suggestions that an unspecified entity 'buy women and children out of existing brothels' to those who argue more obliquely that 'ultimately, I think it is about redemption and hope.' The overall trend, however, can be distilled into a simple phrase from one evangelical respondent: 'emergency rescue services.'

Mainline respondents tended, for their part, to emphasize solutions that involve collaboration with, or governmental, reformation. Collaboration comes in many forms, whether in the creation of new programs, the facilitation of a combination of rescue, boycotts and corporate responsibility, 'changing the way sex and power are portrayed,' or 'monitoring human rights.' Here the most heterogeneity can be seen, with respondents suggesting better educational systems, sociopolitical change, increased governmental support, a change in the tax system, more government oversight, sanctuary cities, the establishment of a social safety net, and changes to economic policies. Some go a step further, recommending to 'Disband the FBI 
and local depts. And give authority to state-side departments with citizen oversight and close federal monitoring. Decriminalize minor drug use and fill the prisons with those who perpetuate slavery.' Such an approach puts 'prosecute perpetrators' in a considerably different light. While some mainline respondents suggest direct interventions into situations of exploitation, their recommendations are far more often framed in terms of structural factors and processes.

While this analysis covers the bulk of the evangelical respondents, a number of these respondents do not conform to this trend. Take, for example, the same relatively conservative attendee of Boston Evangelical mentioned earlier. She saw the problem as 'societal sin' and went on to explain that the situation was to 'Unite and organize - people of faith and secular - to pool together the best of their time, resources, and gifts and work together until the economic structure is changed, no matter how long it takes.' This same understanding of structural or societal sin can be seen in the answers given by one other respondent - a single, evangelical graduate student in her mid-20s - who suggested that exploitation is rooted in the 'structure of failure on behalf of those in political and economical situations' as well as the 'fall of the world and sin on an individual and communal level.' The solution she advanced, however, was that the victim 'should be rescued and helped to find a job that could help her family. She should be helped in healing from the incident, hopefully to the extent that she can one day forgive the farmer and others. The farmer should be prosecuted and exhorted to repent and live differently.' In this response, and among many respondents, there is a clear gap between a structural analysis of the problem (or a belief in structural sin) and the clear articulation of structural solutions.

The similarities within, but not across, evangelical and mainline responses suggest that these two groups are drawing on radically different conceptual schemas when asked to frame the issue. This pattern emerges in those cases where respondents were required to think creatively using the cultural and conceptual resources at their disposal. My analysis rests on the argument that the extant cultural and conceptual resources at evangelicals' disposal disproportionately suggest solutions rooted in intervention focused on the individual victim. The data are clear in presenting evangelicals focused on individually oriented and immediate solutions: punishing the perpetrator and providing jobs and education to rescued victims. Evangelicals uniquely conceptualized the cause of slavery and trafficking as both personal (lack of education or skills) and cosmic (the presence of sin and evil) while suggesting that the solution lay in the provision of individual-level emergency rescue services.

\section{Conclusion}

This study set out to explore an empirical question (How do contemporary evangelicals conceptualize the cause of and solution to modern forms of slavery?) as well as a theoretical puzzle (Why does this happen?). Qualitative analysis suggests an evangelical worldview that sees individuals involved in trafficking as victims of 
individual exploitation and in need of (secular) salvation by intervening others. This conclusion is born out in early quantitative analysis of a subset of congregations as well.

Preliminary quantitative analysis for a subset of churches (Boston Mainline, Boston Progressive and Boston Evangelical) supports the article's qualitative findings at a number of key junctures. Evangelical identification is negatively correlated with structural assessments of the causes of human trafficking $\left(-0.5105^{*}\right)$ and negatively correlated with structural solutions $\left(-0.6493^{*}\right)$. Furthermore, the impact of church affiliation shows that individuals attending evangelical churches are much less likely to think structurally about causes $(-1.9954 * * *)$ and solutions $(-2.8230 * * *)$ than mainline attendees $(0.4197$ and 0.2992 , respectively). In line with the literature is the finding that education is positively correlated with an individual's assessment of structural causes $\left(1.4465^{* *}\right)$ and structural solutions $\left(1.09^{* *}\right)$. Of interest for future investigation is the fact that both conservative $(2.0779 * * *)$ and liberal respondents $\left(2.2245^{* * *}\right)^{4}$ were more likely to identify structural causes than moderate respondents in the vignettes across a number of models (with liberal respondents consistently providing the strongest coefficients, and the finding not holding for the identification of structural solutions). As indicated by this study's qualitative analysis, respondents' belief in structural sin did not have any significant effect on identification of structural causes $(-1.0119)$ or structural solutions (0.4016).

Both qualitative and quantitative findings suggest an articulation of Young's work into the contemporary context. I propose the existence of a salvation schema that draws on the crucial evangelical doctrine of salvation to recommend that contemporary slavery be ended through the provision of 'emergency rescue services.' I argue such a schema represents a deeply held and relatively stable conceptualization of slavery and emancipation, i.e., a cultural resource that lies below the strategic act of framing (Gillan, 2008, p. 247). Here it is the idea of personal salvation that serves as the crucial social and mental category that undergirds evangelical abolitionism. Seen in this light salvation is not only crucial for the individual Christian (Hunter, 1987), it is also explicitly turned outward through the biblical imperative to 'seek and save the lost' (Luke 19:10 English Standard Version) and to 'seek justice, rescue the oppressed' (Isaiah 1:17 English Standard Version). Thus, the term salvation schema suggests those social and mental categories which emerge from the essential evangelical Christian message that individuals are lost and in need of salvation (Hammond \& Hunter, 1984). It is this conceptualization of the other ('lost') and one's duty to the other (to 'rescue' and 'save') that is transposed beyond the context in which it was originally learned (the church) (Sewell, 1992, p. 17). This commitment can be helpfully compared to mainline Protestants for whom salvation is important, but is significantly mediated by other commitments considered core individual religious practice.

Where Young (2006, p. 17) sees the 'syntactical structure of this vocabulary centered on the corrupting power of sin and the redeeming power of confession,' 
this study suggests this vocabulary has more recently pivoted to the redeeming power of salvation. The twin emphasis on individual salvation tends to produce a commitment to immediate emancipation that lacks a structural critique. This shift in emphasis from structural to individual critiques of slavery is significant. While confessionalism expanded structural analysis in 1830 (Young, 2002) the concept of salvation constrains such analysis in the contemporary context. Thus, Young proposes that a cultural mechanism combining the evangelical schemas of public confession and the special sins of the nation launched and sustained interregional protests, whereas I argue the blending of evangelical schemas of sin and individual salvation has reignited and sustained globally focused activism. While the former resulted in abolition, it remains to be seen whether the latter serves as more than a gateway to human rights advocacy for young evangelicals. It is quite possible that subsequent advocacy may profitably harness the latent potential of evangelicals' belief in structural sin and effectively link it to the analysis of critical social issues. The belief in corporate sin suggests that the gap between theology (corporate sin) and practical recommendations (salvationstyle rescue) could be closed through the reframing of this issue by entrepreneurial advocates.

These preliminary findings inform discussions occurring among scholars of religion as well as social movements while raising a broader question for subsequent study: what is the relationship between evangelical perceptions and broader cultural perceptions? The contemporary abolitionist movement, if we can use this framework to describe current advocacy, is occurring against a larger context punctuated by large-scale shifts toward market-based economies, regions of increased secularization and radical shifts in political and social contexts. Elizabeth Bernstein has noted the broader transformation as mainstream feminists have shifted from 'a redistributive model of justice and toward a politics of incarceration' while at the same time a younger generation of evangelicals are moving leftward, 'away from the isolationist issues of abortion and gay marriage and toward a globally oriented social justice theology' (Bernstein, 2010, p. 47). The importance of this broader context is lurking just behind this current study, as most respondents reported having heard about human trafficking through the media.

These broader societal factors raise critical questions regarding how deeply this schema is rooted. Evangelicals may be different from mainliners, but a brief review of contemporary advocacy literature suggests the salvation schema found among evangelicals may represent a more broadly understood, culturewide salvation narrative, which has its roots within, but resonance beyond this explicit and particular religious context. Because this issue has, since its rediscovery, been framed in large part by evangelicals, it is reasonable to assume the media accounts reported by respondents are rooted in the same salvation schema advanced through the Bush Administration's framing of the issue. This possibility - that support for the salvation schema can also be identified in 
earlier (and broader) media and governmental data - seems worthy of further investigation.

While this study has suggested evangelicals choose individual rescue over structural reform because of a commitment to 'seek and save the lost,' it has spent less time exploring why contemporary evangelicals' priorities have shifted over the past 150 years. Young identifies three components of the extensive and rapid social change which led evangelicals to nation-redeeming social action in the 1830s: (1) political, economic, demographic, and religious pressures; (2) loss of ecclesiastical authority over communities; and (3) fundamental changes in religious doctrine and practices (Young, 2002, p. 664). In a similar vein Christian Smith has suggested American evangelicals are currently experiencing a number of interconnected pressures stemming from: (1) a perceived need for 'socially constructed cultural distinction vis-à-vis a vigorous sociocultural engagement with pluralistic modernity' (C. Smith, Emerson, Gallagher, Kennedy, \& Sikkink, 1998, p. 121); (2) cultural upheaval in the form of 'moral relativism, social decay, [and] homosexual rights' (p. 144); and (3) 'rapid sociocultural changes and the accompanying relativism that typify modernity,' which, in turn, intensifies felt needs and desires for 'stability, assurance, and truth' (p. 144). According to Smith, this upheaval is punctuated by an increased individualism that affects evangelical belief. Hopefully this study opens additional avenues for further exploration along these lines.

This study has also left unanswered the role of gender and sexuality in evangelicals' salvation narratives. Various constraints have focused our attention on the comparison between religious traditions, rather than the comparison of responses from men with those from women. Also fruitful would be an analysis of the differences in response based on the various combinations of gender and exploitation type in the vignettes. Are evangelicals more likely to recommend rescue for women in sexual exploitation than labor exploitation? Likewise, are mainline respondents more likely to recommend structural solutions in cases where men are held in labor exploitation? With any luck, this study has laid the groundwork for a number of hypotheses that I hope will be taken up at some later date.

Finally, subsequent research may illuminate whether other evangelical efforts to engage in social action draw on a salvation schema, or whether it is unique to anti-slavery work. It seems reasonable to expect that the notion of salvation corresponds with evangelical efforts to rescue fetuses from abortion, yet it remains to be seen whether it also fits with evangelical engagement in the environmental movement and prison reform. In conclusion, it is my hope that these preliminary findings suggest new avenues of research for the growing literature on evangelical engagement in public life generally and social movements for human rights in particular, while also bridging the literature on evangelical engagement with an evergrowing community of organizations, policymakers and researchers interested in understanding and ending contemporary forms of slavery. 


\section{Notes}

1. I am grateful to Michael Young for pointing out the distinction with earlier evangelicals, who 'still held to remnants of the collective covenant tradition. ... [I]ndividual sins are punished by [God] in the afterworld but collective problems must be punished in the here and now - hence poverty, prostitutions, slavery, etc. were not just individual sins but collective failings and reformers promised divine justice in the here and now if the covenanted community did not repent' (personal communication, 2010).

2. The General Social Survey is a major American institution and can be retrieved from here: http://www.thearda.com/Archive/Files/Descriptions/GSS1998.asp

3. Female, middle-aged (49), middle-class, college educated, politically liberal, theologically conservative. Believes in the importance of faith, the existence of heaven, hell and sin, looks to scripture and the church for guidance and considers Christ the only path to salvation. Not particularly opinionated about whether the world and human nature are fundamentally corrupt or good.

4. $* \mathrm{p}<.05 ; * * \mathrm{p}<.01 ; * * * \mathrm{p}<.001$ (one-tailed tests).

\section{References}

Alexander, C., \& Becker, H. (1978). The use of vignettes in survey research. Public Opinion Quarterly, 42, 93-104.

Allain, J., \& Bales, K. (2011). Slavery and its definition. Queen's University Belfast Law Research Paper No. 12-06.

Bales, K. (2012). Disposable people: New slavery in the global economy, (3rd ed.). Berkeley and Los Angeles: University of California Press.

Bartlett, F. C. (1932). Remembering: A study in experimental and social psychology. Cambridge: Cambridge University Press.

Benford, R. D. (1997). An insider's critique of the social movement framing perspective. Sociological Inquiry, 67, 409-430.

Berman, J. (2006). The left, the right, and the prostitute: The making of US antitrafficking in persons policy. Tulane Journal of International and Comparative Law, 14, 269-293.

Berman, J. (2010). Staging 'A special evil': Trafficking in women, male victimization, and heroic return of sovereignty. Paper presented at the International Studies Association Annual Meeting, New Orleans, LA.

Bernstein, E. (2007). The sexual politics of the 'new abolitionism.' Differences, 18(3), $128-151$.

Bernstein, E. (2010). Militarized humanitarianism meets carceral feminism: The politics of sex, rights, and freedom in contemporary anti-trafficking campaigns. Signs, 36, 45-71.

Brysk, A., \& Choi-Fitzpatrick, A. (Eds.). (2012). From human trafficking to human rights: Reframing contemporary slavery. Philadelphia: University of Pennsylvania Press.

Charmaz, K. (2000). Grounded theory: Objectivist and constructivist methods. In N. Denzin \& Y. Lincoln (Eds.), Handbook of qualitative research (2nd ed., pp. 509535). Thousand Oaks, CA: Sage.

Choi-Fitzpatrick, A. (2012). Rethinking trafficking: Contemporary slavery. In A. Brysk \& A. Choi-Fitzpatrick (Eds.), From human trafficking to human rights: Reframing contemporary slavery (pp. 13-24). Philadelphia: University of Pennsylvania Press.

Choi-Fitzpatrick, A. (n.d.). A human rights approach to contemporary slavery. Unpublished.

Church of the Brethren Statements on Slavery. (2008). Retrieved from www.brethren.org/ advocacy/documents/statements-on-modern-day.pdf

Collett, J., Guidry, T., Martin, N., \& Sager, R. (2006). Faith-based decisions? The consequences of heightened religious salience in social service referral decisions. Journal for the Scientific Study of Religion, 45, 119-127. 
Davis, D. B. [1962] (1999). Emergence of immediatism in British and American antislavery thought. In J. R. McKivigan (Ed.), Abolitionism and American reform (pp. 1-23). Abingdon: Taylor \& Francis.

Desyllas, M. C. (2007). A critique of the global trafficking discourse and US policy. Journal of Sociology and Social Welfare, 34, 57-79.

Doezema, J. (2000). Loose women or lost women? Gender Studies, 18, 23-50.

Duguay, C. (Director), Doyle, C. (Writer), \& Dominik, A. (Writer). (2006). Human trafficking [Television series]. Lifetime Television and Muse. Muse Entertainment Enterprises: Filmed in Montreal, Bangkok and Prague.

Emirbayer, M., \& Mische, A. (1998). What is agency? American Journal of Sociology, 103, $962-1023$.

Fetner, T. (2008). How the religious right shaped lesbian and gay activism. Minneapolis: University of Minnesota Press.

Fitzgerald, S. T. (2009). Cooperative collective action: Framing faith-based community development. Mobilization, 14, 181-198.

General Social Survey (GSS). (1998). Retrieved from http://www.thearda.com/Archive/ Files/Descriptions/GSS1998.asp

Gillan, K. (2008). Understanding meaning in movements: A hermeneutic approach to frames and ideologies. Social Movement Studies, 7, 247-263.

Goffman, E. (1974 [1986]). Frame Analysis: An essay on the organization of experience. Boston, MA: Northeastern University Press.

Grittner, F. K. (1986). White slavery: Myth, ideology, and American law. Milwaukee: University of Minnesota.

Hammond, P. E., \& Hunter, J. D. (1984). On maintaining plausibility: The worldview of evangelical college students. Journal for the Scientific Study of Religion, 23, 221-238.

Heltzel, P. G. (2009). Jesus and justice: Evangelicals, race, and American politics. Hartford, CT: Yale University Press.

Hertzke, A. D. (2004). Freeing God's children: The unlikely alliance for global human rights. Oxford: Rowman \& Littlefield.

Hochschild, A. (2005). Bury the chains: Prophets and rebels in the fight to free an empire's slaves. New York, NY: Houghton Mifflin Harcourt.

Hunter, J. D. (1982). Subjectivization and the new evangelical theodicy. Journal for the Scientific Study of Religion, 21, 39-47.

Hunter, J. D. (1987). Evangelicalism: The coming generation. Chicago, IL: University of Chicago Press.

Johnston, H. (1995). A methodology for frame analysis: From discourse to cognitive schemata. In H. Johnston \& B. Klandermans (Eds.), Social movements and culture (pp. 217-246). Minneapolis: University of Minnesota Press.

Jordan, A. (2007). Testimony before the House Subcommittee on Border, Maritime and Global Counterterrorism, March 20, US House of Representatives. Retrieved from http://chsdemocrats.house.gov/SiteDocuments/20070320165954-38416.pdf

Kristof, N. (2004, December 22). Where the right is right. The New York Times, p. A31.

Landesman, P. (2004, January 25). The girl next door. The New York Times Magazine. Retrieved from http://www.nytimes.com/2004/01/25/magazine/25SEXTRAFFIC.html

Lichterman, P. (2008). Religion and the construction of civic identity. American Sociological Review, 73, 83-104.

Lindsay, M. D. (2007). Faith in the halls of power: How evangelicals joined the American elite. Oxford: Oxford University Press.

Loveland, A. (1966). Evangelicalism and 'immediate emancipation' in American Antislavery Thought. Journal of Southern History, 32, 172-188.

McAdam, D., McCarthy, J.D., \& Zald, M.N. (1996). Introduction: Opportunities, mobilizing structures, and framing processes: Toward a synthetic, comparative perspective on 
social movements. In D. McAdam, J.D. McCarthy, \& M.N. Zald (Eds.), Comparative Perspectives on Social Movements: Political opportunities, mobilizing structures, and cultural framings (pp. 1-22). Cambridge: Cambridge University Press.

McDonald, W. (2004). Traffic counts, symbols and agendas: A critique of the campaign against trafficking of human beings. International Review of Victimology, 11, 143-176.

Morris, A. (1986). Origins of the civil rights movement: Black communities organizing for change. New York: Free Press.

Munson, Z. (2008). The making of pro-life activists: How social movement mobilization works. Chicago, IL: University of Chicago Press.

Nepstad, S. E. (2004). Persistent resistance: Commitment and community in the plowshares movement. Social Problems, 51, 43-60.

Noll, M. (1994). The scandal of the evangelical mind. Grand Rapids, MI: Wm. B. Eerdmans.

Outshoorn, J. (2005). The political debates on prostitution and trafficking of women. Social Politics, 12, 141-155.

Quirk, J. (2011). The anti-slavery project: From the slave trade to human trafficking. Philadelphia: University of Pennsylvania Press.

Sewell Jr., W. H. (1992). A theory of structure: Duality, agency, and transformation. American Journal of Sociology, 98(1).

Shapiro, N. (2004, August 25). The new abolitionists. Seattle Weekly. Retrieved from http:// www.seattleweekly.com/2004-08-25/news/the-new-abolitionists/

Sharma, N. (2005). Anti-trafficking rhetoric and the making of a global apartheid. NWSA Journal, 17(3), 88-111.

Smith, B. G., \& Johnson, B. (2010). The liberalization of young evangelicals: A research note. Journal for the Scientific Study of Religion, 49, 351-360.

Smith, C. (1996a). Disruptive religion: The force of faith in social movement activism. New York, NY: Routledge.

Smith, C. (1996b). Resisting Reagan: The US Central America peace movement. Chicago, IL: Chicago University Press.

Smith, C., Emerson, M., Gallagher, S., Kennedy, P., \& Sikkink, D. (1998). American evangelicalism: Embattled and thriving. Chicago, IL: University of Chicago Press.

Snow, D A., Burke Rochford, Jr. E., Worden, S. K., and Benford, R. D. (1986). Frame alignment processes, micromobilization, and movement participation. American Sociological Review, 51(4): 464-481.

Soderlund, G. (2005). Running from the rescuers: New US crusades against sex trafficking and the rhetoric of abolition. NWSA Journal, 17(3), 64-87.

Steensland, B., \& Goff, P. (Eds.). (2014). The new evangelical social engagement. Oxford: Oxford University Press.

Strauss, Anselm. (1987). Qualitative analysis for social scientists. Cambridge: Cambridge University Press.

Tilly, C. (1997). Roads from past to future. Lanham, Md: Rowman \& Littlefield Publishers.

United Nations. (2000). Protocol to prevent, suppress and punish trafficking in persons, especially women and children, supplementing the United Nations Convention against Transnational Organized Crime. Retrieved from http://www.uncjin.org/ Documents/Conventions/dcatoc/final_documents_2/convention_\%20traff_eng.pdf

Vance, C. S. (2011). Thinking trafficking, thinking sex. GLQ, 17, $\overline{135}-143$.

Weitzer, R. (2007). The social construction of sex trafficking: Ideology and institutionalization of a moral crusade. Politics \& Society, 35, 447-475.

Wood, J. R, \& Zald, M. N. (1987). Aspects of racial integration in the methodist church: Sources of resistance to organizational policy. In M. Zald, \& J. McCarthy (Eds.), Social movements in an organizational society: Collected essays (pp.223-246). Transaction Publishers. 
Wood, R. L. (2002). Faith in action: Religion race and democratic organizing in America. Chicago, IL: University of Chicago Press.

Wuthnow, R. (1999). Mobilizing civic engagement: The changing impact of religious involvement. In T. Skocpol \& M. Fiorina (Eds.), Civic engagement in American democracy (pp. 331-362). Washington, DC: Brookings Institution Press.

Young, M. P. (2002). Confessional protest: The religious birth of US national social movements. American Sociological Review, 67, 660-688.

Young, M. P. (2006). Bearing witness against sin: The evangelical birth of the American social movement. Chicago, IL: University of Chicago Press.

Zhao, D. (2010). Theorizing the role of culture in social movements: Illustrated by protests and contentions in modern China. Social Movement Studies, 9, 33-50. 